\title{
Tribute to George F. Ledingham (1911-2006), a Conservation Leader for Western Canada
}

\author{
Daniel F. Brunton ${ }^{1,3}$, C. Stuart Houston ${ }^{2}$, and Mary I. Houston ${ }^{2}$ \\ ${ }^{1} 216$ Lincoln Heights Road, Ottawa, Ontario K2B 8A8 Canada \\ 2863 University Drive, Saskatoon, Saskatchewan S7N 0J8 Canada \\ ${ }^{3}$ Corresponding author; email: bruntonconsulting@rogers.com
}

Brunton, Daniel F., C. Stuart Houston, and Mary I. Houston. 2013. Tribute to George F. Ledingham (1911-2006), a conservation leader for western Canada. Canadian Field-Naturalist 127(1): 76-81.

"Society ... must take a strong stand for conservation. In a democracy, we cannot expect to have the problems of conservation and wildlife management solved intelligently without an informed public".

Readers will be forgiven if they think this is a new challenge to Canadians from an expert body that believes the present federal government is on a path of unconscionable suppression of nationally important environmental research and monitoring programs. It is actually a clarion call from the past to the Saskatchewan Natural History Society (SNHS - now Nature Saskatchewan) to refocus itself as an advocate of the protection of natural environmental values in western Canada. And far from being a contemporary challenge, it was written in 1956, over half a century ago.

Saskatchewan native George Filson Ledingham (31 January 1911 - 18 October 2006, Figure 1) wrote that in his capacity as incoming editor of The Blue Jay, the excellent natural sciences journal of the SNHS (Ledingham 1956). He was editor for 16 years, reshaping the journal into the premier publication of its kind in the prairie provinces. In the course of his editorship, as in numerous public presentations, deputations to provincial and federal governments, co-operative ventures with various non-governmental conservation organizations, and one-on-one dealings with innumerable fellow naturalists, he was a consistently strong advocate of the need to conserve natural areas and wildlife. It's tempting to say George Ledingham was ahead of his time. It's probably more accurate to suggest that he was very much of his time but at the front of the pack.

As noted in the reviews of Ledingham's life and career by Fahselt (2007) and Houston and Nero (2006), conservation action was not his "day job." His career as a biology professor and well-respected teacher at Regina College (later the University of Regina) extended from 1946 until 1976, continuing with part-time teaching until 1983 (Houston and Nero 2006). He was an authority on the cytology of Oxytropis and Astragalus, both agriculturally and ecologically important plant genera in the bean (Fabaceae) family that are well represented in prairie landscapes. Fieldwork for his investigation of these plants likely contributed to

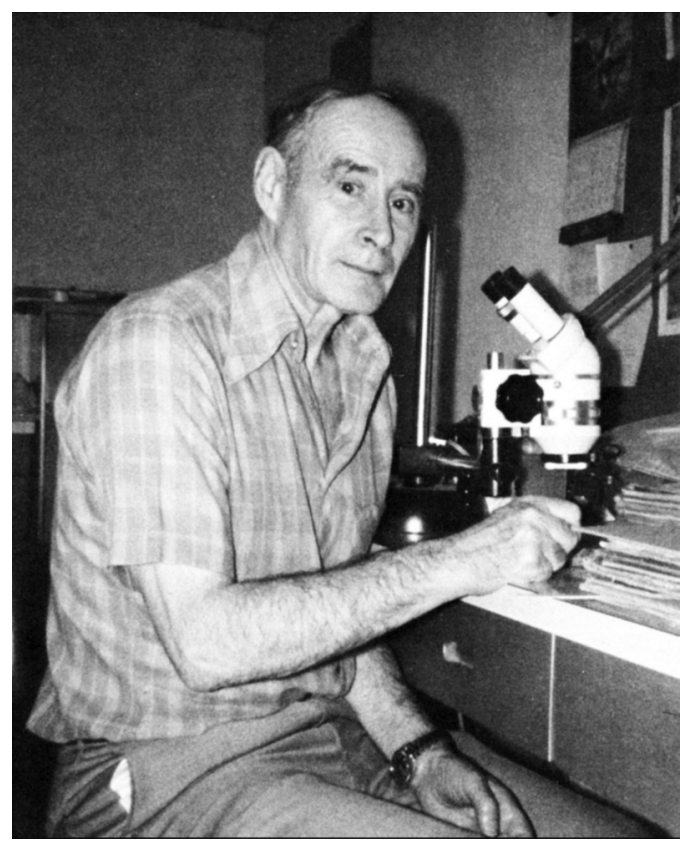

FIGURE 1. George Ledingham in 1982. Photo: Gary Seib.

his lifelong love of native prairie and to his tireless efforts to conserve and protect native examples of it.

The prairie was in his blood. George Ledingham was born into a large family with five siblings on a farm west of Moose Jaw, Saskatchewan. Initially trained as a public school teacher, he later obtained a B.Sc. (1934) and M.Sc. (1936) from the University of Saskatchewan, venturing beyond the province to earn a Ph.D. from the University of Wisconsin in 1939. He married University of Saskatchewan graduate (B.A., 1939) Marjorie Clare Beattie in June 1942. He was predeceased by Marjorie in March 2000 but was survived by their son, Beattie, three grandsons, and four great-granddaughters (see Houston and Nero 2006 for further details of his personal background). 


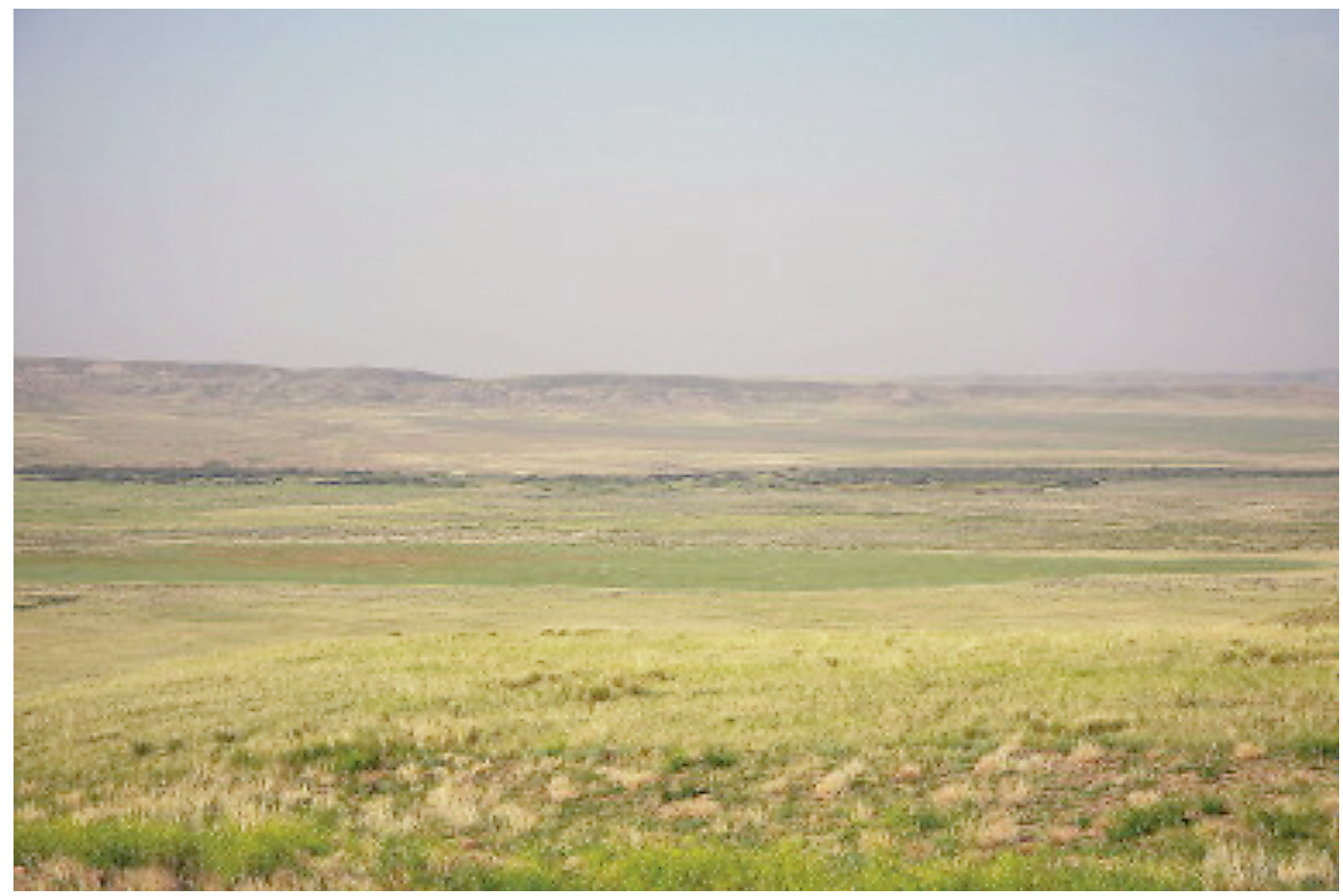

FIGURE 2. Native prairie in the Frenchman River valley, Grasslands National Park, Saskatchewan, 1 July 2008. Photo: D. F. Brunton.

Ledingham's notable scientific contributions include his role in the founding and development of the 70000 -specimen herbarium of the University of Regina (USAS) (herbarium acronym follows Thiers 2012). He was also widely credited as being a major influence in developing the careers of his students (Fahselt 2007). His proudest legacy, however, is undoubtedly his success in obtaining protection for important examples of native grasslands. More than that of any other individual, his persistence in conducting research and public education and in lobbying for over 30 years was responsible for the creation in 1989 of Grasslands National Park in southwestern Saskatchewan (Houston and Nero 2006) (Figure 2).

Ledingham's efforts on behalf of the naturalist community in Saskatchewan were exceptional. It is difficult, for example, to overstate his importance in the establishment and early success of the SNHS. In August 1948, when he was President of the Regina Natural History Society, he received a letter from the Yorkton Natural History Society (drafted by C. Stuart Houston) exploring the possibility of provincial co-operation in the publication of their local Yorkton journal, The Blue Jay. Ledingham responded positively but went further by suggesting the formation of a province-wide naturalists' federation that would be more than just the publisher of the journal (Belcher 1996). This, the Saskatchewan Natural History Society, would provide improved communications and support within the provincial naturalist community and offer greater opportunities for both public educational and effective wildlife conservation measures.

Ledingham was appointed provisional president of the SNHS at the 24 January 1949 formative gathering of local natural society representatives in Regina. The following year he became the first president elected by the membership, thus presiding over the crucial early days of the organization and initiating decades of service in various administrative and organizational capacities. A dramatic illustration of the importance and endurance of his involvement is evident in Figure 3. Each coloured page marker indicates a page in Margaret Belcher's comprehensive history of the SNHS where mention of one or more of George Ledingham's contributions to the Society appears.

It is a remarkable record. Throughout his lengthy history of action and concern, however, George Ledingham never lost focus on the need for Saskatchewan naturalists to be well informed about their landscape, to share that knowledge in the pages of The Blue Jay and elsewhere, and to be persistent in ensuring that important prairie landscapes were protected.

Amongst the many accolades he received for his long and productive professional and community career was the naming of the University of Regina herbarium in his honour (Anonymous 2006). He continued to con- 
duct curatorial and taxonomic work there well into his 90s. The University of Regina also conferred an honorary doctorate on him in November 1986 (Anonymous 1986).

In 1981 he received the $\mathrm{J}$. B. Harkin Medal from the National and Provincial Parks Association of Canada (now Canadian Parks and Wilderness Society) for his contribution to the conservation of native grasslands in the prairie provinces (Belcher 1982).

Ledingham was awarded an Honorary Membership by the Ottawa Field-Naturalists' Club in 1992. The citation includes the following:

"There is a rich and special connection between prairie people and the land. This productive and often eloquent relationship has produced remarkable interpreters of western grasslands, be they writers like W. O. Mitchell, painters like William Kurelek, or scientists like George Ledingham. ... If Black-footed Ferrets once again hunt prairiedogs on the open Canadian prairie it will happen here and only because of the effort and dedication of Ledingham and his associates" (Brunton 1993).

That the once almost extinct Black-footed Ferret (Mustela nigripes) is indeed now hunting Black-tailed Prairie Dogs (Cynomys ludovicianus) on the native prairie of Grasslands National Park underscores the importance of that vision and his perseverance.

Like the man himself, one especially important legacy of George Ledingham is understated and subtle. That is his role from the late 1950s into the 1980 s as a spokesperson for and interpreter of the conservation ethic that was developing in western Canada and across North America. His well-expressed, science-based writings - especially his editorials in The Blue Jay (see appended bibliography) - influenced a generation of western Canadian naturalists.

Here was a man who was totally at home on the prairie, who knew it well, who communicated that knowledge with credibility and respect, and who made a lasting and important contribution to the protection of its native biodiversity. His inspiration continues to pay conservation dividends, in both the work of organizations like Nature Saskatchewan and the initiatives of individual prairie naturalists.

\section{Acknowledgements}

Our thanks to Gary Seib of Regina, Saskatchewan for permission to use the Ledingham photograph. An earlier draft of the manuscript benefited from the review by Karen L. McIntosh of Ottawa, Ontario, as did the final draft from comments by Associate Editor of Tributes Francis Cook.

\section{Literature Cited}

Anonymous. 1986. Honorary degree: Dr. George Ledingham. Blue Jay 44(4): 263.

Anonymous. 2006. The plant man: George Ledingham's 60year project. Degrees 18(2): 21-25.

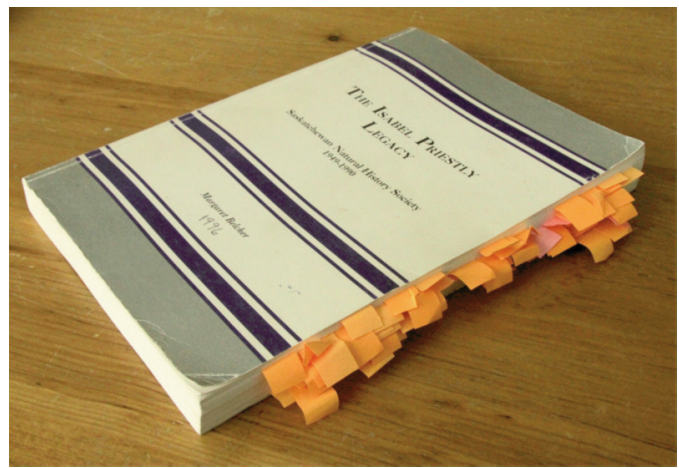

FIGURE 3. Pages marked with numerous Ledingham references in the history of the Saskatchewan Natural History Society (Belcher 1996).

Belcher, M. 1982. Vigilance needed in the Grasslands. Blue Jay 40(2): 67-68.

Belcher, M. 1996. The Isabel Priestly legacy: Saskatchewan Natural History Society, 1949-1990. Saskatchewan Natural History Society, Regina, Saskatchewan. 287 pages.

[Brunton, D. F.] 1993. 1992 Honorary Member, George F. Ledingham. Page 247 in The Ottawa Field-Naturalists' Club 1992 Awards. Compiled by E. Frankton. Canadian Field-Naturalist 107: 247-250.

Fahselt, D. 2007. Obituary: George Ledingham, 1911-2006. Canadian Botanical Association Bulletin 39: 53-54.

Houston, C. S., and R. W. Nero. 2006. George F. Ledingham, 1911-2006. Blue Jay 64(4): 225-227.

[Ledingham, G. F.] 1956. [Editorial] Blue Jay Chatter [new editorial team; conservation priority for the Saskatchewan Natural History Society]. Blue Jay 14(1): inside front cover.

Thiers, B. 2012. Index Herbariorum: A Global Directory of Public Herbaria and Associated Staff. New York Botanical Garden Virtual Herbarium. http://sweetgum.nybg.org /ih/. (Accessed 22 December 2012).

\section{Bibliography of George F. Ledingham}

Ledingham, G. F., and W. P. Thompson. 1938. The cytogenetics of non-amphidiploid derivatives of wheat-rye hybrids. Cytologic 8: 377-397.

Ledingham, G. F. 1940. Cytological and developmental studies of hybrids between Medicago sativa and a diploid form of M. falcata. Genetics 25: 1-15.

Ledingham, G. F., and W. P. Fraser.1943. Notes on the Cyperaceae II. Carex. American Midland Naturalist 29: $42-50$.

Ledingham, G. F. 1949. Museum notes. Blue Jay 7(1): 28.

Ledingham, G. F. 1949. The President's report. Blue Jay 7(4): 3-4.

Ledingham, G. F. 1950. One of our members [Dick Bird] Honoured. Blue Jay 8(4): 3.

Ledingham, G. F. 1952. The first spring flower [Cypripedium acaule]. Blue Jay 10(2): 17.

Ledingham, G. F. 1953. Natural history and farming. Blue Jay 11(1): inside back cover.

Ledingham, G. F. 1953. Further aims of the society. Blue Jay 11(2): 14

Ledingham, G. F. 1954. The Secretary's corner [SNHS news]. Blue Jay 12(1, 2 and 4): inside back cover. 
Russell, R. C., G. F. Ledingham, and R. T. Cowpland. 1954. An annotated list of the plants of Saskatchewan. Revised. University of Saskatchewan, Saskatoon, Saskatchewan. 47 pages.

Ledingham, G. F. 1955. The Secretary's corner [SNHS news]. Blue Jay 13(1, 2, 3 and 4): inside back cover.

[Ledingham, G. F.] 1956. [Editorial] Blue Jay Chatter [new editorial team; conservation priority for SNHS]. Blue Jay 14(1): inside front cover.

[Ledingham, G. F.] 1956. [Editorial] Blue Jay Chatter [wildlife conservation needs]. Blue Jay 14(2): inside front cover.

[Ledingham, G. F.] 1956. [Editorial] Blue Jay Chatter [conservation awareness needs; Blue Jay activities]. Blue Jay 14(3): inside front cover.

[Ledingham, G. F.] 1956. [Editorial] Blue Jay Chatter [AOU Denver Meeting; SNHS Annual Meeting discussions]. Blue Jay 14(4): inside front cover.

[Ledingham, G. F.] 1957. [Editorial] Blue Jay Chatter: Whooping Cranes; Larger Blue Jay. Blue Jay 15(1): inside front cover.

[Ledingham, G. F.] 1957. [Editorial] Blue Jay Chatter [SHNH and conservation news]. Blue Jay 15(2): inside front cover.

Ledingham, G. F. 1957. How to collect and press plants. Blue Jay 15(2): 76-77.

[Ledingham, G. F.] 1957. [Editorial] Blue Jay Chatter [visiting naturalists]. Blue Jay 15(3): inside front cover.

Ledingham, G. F. 1957. Chromosome numbers of some Saskatchewan Leguminosae with particular reference to Astragalus and Oxytropis. Canadian Journal of Botany 35: 657-666.

[Ledingham, G. F.] 1958. [Editorial] Blue Jay Chatter [Christmas Bird Counts; deaths of long-time SNHS members Arthur Ward and Mrs. Albert Mudiman]. Blue Jay 16(1): inside front cover

[Ledingham, G. F.] 1958. [Editorial] Blue Jay Chatter [SNHS meetings; mammal publications]. Blue Jay 16(2): inside front cover.

[Ledingham, G. F.] 1958. [Editorial] Blue Jay Chatter [protection of raptors]. Blue Jay 16(3): inside front cover.

[Ledingham, G. F.] 1958. [Editorial] Blue Jay Chatter: Guide to the Mammals of Saskatchewan; AOU meets in Regina August 1959. Blue Jay 16(4): inside front cover.

Ledingham, G. F. 1958. Chromosome numbers in Astragalus. Proceedings of the Genetics Society of Canada 3(2): $15-18$.

[Ledingham, G. F.] 1959. [Editorial] Blue Jay Chatter: James Alexander Munro, Publications, Meetings. Blue Jay 17(1): inside front cover.

[Ledingham, G. F.] 1959. [Editorial] Blue Jay Chatter [pesticide impact on wildlife]. Blue Jay 17(2): inside front cover.

[Ledingham, G. F.] 1959. [Editorial] Blue Jay Chatter [American Ornithologist's Union meeting; visiting scientists W.W. Gunn; F.R. Cook]. Blue Jay 17(3): inside front cover.

[Ledingham, G. F.] 1959. The American Ornithologists' Union. Blue Jay 17(3): 87-88.

Ledingham, G. F. 1959. The Isabel M. Priestly plant collection. Blue Jay 17(3): 118-119.

[Ledingham, G. F.] 1959. [Editorial] Blue Jay Chatter [SNHS achievements]. Blue Jay 17(4): inside front cover.
[Ledingham, G. F.] 1959. Sandhill Cranes: a conservation problem. Blue Jay 17(4): 140.

Ledingham, G. F. 1959. Red Crossbill feeding on aphids. Blue Jay 17(4): 149.

Ledingham, G. F. 1959. A second Canadian record of Oxytropis besseyi. Blue Jay 17(4): 162.

[Ledingham, G. F.] 1960. [Editorial] Blue Jay Chatter [predator conservation needs]. Blue Jay 18(1): inside front cover.

[Ledingham, G. F.] 1960. [Editorial] Blue Jay Chatter [conservation activities]. Blue Jay 18(2): inside front cover.

[Ledingham, G. F.] 1960. [Editorial] Blue Jay Chatter [raptor protection; SNHS annual meeting notice]. Blue Jay 18(3): inside front cover.

Ledingham, G. F. 1960. Chromosome numbers in Astragalus. Proceedings of the Genetics Society of Canada 3: 15-18.

Ledingham, G. F. 1960. Chromosome numbers in Astragalus and Oxytropis. Canadian Journal of Genetics and Cytology 2: 119-128.

Ledingham, G. F. 1960. Giant puffball. Blue Jay 18(3): 132.

Ledingham, G. F. 1960. Pink Penstemon nitidus. Blue Jay 18(3): 132 .

[Ledingham, G. F.] 1960. [Editorial] Blue Jay Chatter [SNHS Annual Meeting]. Blue Jay 18(4): inside front cover.

Ledingham, G. F. 1960. The Sandhill Crane problem. Blue Jay 18(4): 152-155.

Ledingham, G. F. 1960. Stinkhorns. Blue Jay 18(4): 171.

Ledingham, G. F. 1960. Chromosome numbers in Astragalus and Oxytropis. Pages 870-874 in Recent Advances in Botany. Proceedings of the International Botanical Congress, University of Toronto Press, Toronto, Ontario.

[Ledingham, G. F.] 1961. [Editorial] Blue Jay Chatter [Blue Jay progress]. Blue Jay 19(1): inside front cover.

[Ledingham, G. F.] 1961. [Editorial] Blue Jay Chatter: Let's start a wildlife refuge. Blue Jay 19(2): inside front cover.

[Ledingham], G. F. 1961. Second bobcat collected near Regina. Blue Jay 19(2): 96.

[Ledingham, G. F.] 1961. [Editorial] Blue Jay Chatter [supporting SNHS]. Blue Jay 19(3): inside front cover.

Ledingham, G. F. 1961. [Editorial] Blue Jay Chatter [protecting Saskatchewan wildlife]. Blue Jay 19(4): inside front cover.

[Ledingham, G. F.] 1962. [Editorial] Blue Jay Chatter [SNHS programs]. Blue Jay 20(3): inside front cover.

Ledingham, G. F. 1962. From southern deserts to northern sand dunes. Blue Jay 20(3): 98-102.

Ledingham, G. F. 1962. First report of Lotus corniculatus in Saskatchewan. Blue Jay 20(3): 120.

Ledingham, G. F. 1962. Nature Conservancy of Canada. Blue Jay 20(3): 133.

[Ledingham, G. F.] 1962. [Editorial] Blue Jay Chatter [SNHS achievements]. Blue Jay 20(4): inside front cover.

[Ledingham, G. F.] 1963. [Editorial] Blue Jay Chatter [western Canadian conservation initiatives]. Blue Jay 21(1): inside front cover.

[Ledingham, G. F.] 1963. [Editorial] Blue Jay Chatter [protection of wildlife from hunting]. Blue Jay 21(2): inside front cover.

[Ledingham, G. F.] 1963. [Editorial] Blue Jay Chatter [conservation needs]. Blue Jay 21(3): inside front cover.

Ledingham, G. F. 1963. Partially albino red-wing sighted for fifth year. Blue Jay 21(3): 105. 
[Ledingham, G. F.] 1963. [Editorial] Blue Jay Chatter [SNHS meetings; publication of Nero's Birds of Lake Athabaska]. Blue Jay 21(4): inside front cover.

Ledingham, G. F., and B. M. Rever. 1963. Chromosome numbers of some southwest Asian species of Astragalus and Oxytropis (Leguminosae). Canadian Journal of Genetics and Cytology [Genome] 5: 18-32.

Ledingham, G. F. 1964. [Editorial] Blue Jay Chatter: Saskatchewan's First Resources Conference. Blue Jay 22(1): inside front cover.

[Ledingham, G. F., M. Belcher and R. W. Nero]. The Editors. 1964. [Editorial] Blue Jay Chatter [western Canadian naturalist publications]. Blue Jay 22(2): inside front cover.

Ledingham, G. F. 1964. [Editorial] Blue Jay Chatter [Lazuli Bunting, Lark Bunting, Dickcissel]. Blue Jay 22(3): inside front cover.

Ledingham, G. F. 1964. [Editorial] Blue Jay Chatter [Saguaro cactus]. Blue Jay 22(4): inside front cover.

Ledingham, G. F., and M. D. Fahselt. 1964. Chromosome numbers of some North American species of Astragalus (Leguminosae). Sida 1: 313-327.

[Ledingham, G. F.] 1965. [Editorial] Prairie Dogs and Ferrets. Blue Jay 23(1): inside front cover.

[Ledingham, G. F.] 1965. [Editorial] Far away cranes. Blue Jay 23(2): inside front cover.

Ledingham, G. F. 1965. Nature Conservancy of Canada. Blue Jay 23(2): 111.

[Ledingham, G. F.] 1965. [Editorial] Planning for wild lands. Blue Jay 23(3): inside front cover.

[Ledingham, G. F.] 1965. [Editorial] The love of hunting. Blue Jay 23(4): inside front cover.

[Ledingham, G. F.] 1966. [Editorial] For the sake of abstract values. ... Blue Jay 24(1): inside front cover.

[Ledingham, G. F.] 1966. [Editorial] The remote northern wilderness. Blue Jay 24(2): inside front cover.

Ledingham, G. F. 1966. The quiet crisis. Blue Jay 24(2): 54.

[Ledingham, G. F.] 1966. [Editorial] The responsibility of membership in the Saskatchewan Natural History Society. Blue Jay 24(3): inside front cover.

[Ledingham, G. F.] 1966. [Editorial] Wetlands preservation and waterfowl research. Blue Jay 24(4): inside front cover.

Ledingham, G. F. 1966. Herbarium in Regina. Blue Jay 24(4): 192.

Ledingham, G. F. 1966. Evolution of wildlife conservation in California. Blue Jay 24(4): 205-206.

[Ledingham, G. F.] 1967. [Editorial] What is your special natural history project? Blue Jay 25(1): inside front cover.

Ledingham, G. F. 1967. Editorial [natural history observations]. Blue Jay 25(2): inside front cover.

[Ledingham, G. F.] 1967. [Editorial] Wild Saskatchewan. Blue Jay 25(3): inside front cover.

Ledingham, G. F. 1967. Water pollution. Blue Jay 25(3): 106.

[Ledingham, G. F.] 1967. [Editorial] The Canadian north. Blue Jay 25(4): inside front cover.

[Ledingham, G. F.] 1968. Editorial [SNHS publications and Symons' Hours and the Birds]. Blue Jay 26(1): inside front cover.

Ledingham, G. F. 1968. Editorial [wetland conservation]. Blue Jay 26(2): inside front cover.

[Ledingham, G. F.] 1968. [Editorial] A home for The Blue Jay. Blue Jay 26(3): inside front cover.
Ledingham, G. F. 1968. [Editorial] Preserving wildlife and natural areas. Blue Jay 26(4): inside front cover.

[Ledingham, G. F.] 1969. Editorial [Grasslands National Park]. Blue Jay 27(1): inside front cover.

[Ledingham, G. F.] 1969. [Editorial] What kind of national parks do we want? Blue Jay 27(2): inside front cover.

[Ledingham, G. F.] 1969. [Editorial] The trouble with DDT. Blue Jay 27(3): inside front cover.

[Ledingham, G. F.] 1969. [Editorial] SNHS - A conservationconscious society. Blue Jay 27(4): inside front cover.

[Ledingham, G. F.] 1970. [Editorial] Individual responsibility. Blue Jay 28(1): inside front cover.

Ledingham, G. F. 1970. Grant from Ducks Unlimited. Blue Jay 28(2): 103.

[Ledingham, G. F.] 1970. [Editorial] I Didn't Know .... Blue Jay 28(3): inside front cover.

[Ledingham, G. F.] 1970. [Editorial] Our environmental crisis. Blue Jay 28(4): inside front cover.

[Ledingham, G. F.] 1971. [Editorial] Not a House Sparrow. Blue Jay 29(1): inside front cover.

[Ledingham, G. F.] 1971. [Editorial] The Wildcat Hill Wilderness Area. Blue Jay 29(2): inside front cover.

Ledingham, G. F. 1971. Bruce Trail revisited. Blue Jay 29(2): 105.

[Ledingham, G. F.] 1971. [Editorial] Parks and the people. Blue Jay 29(3): inside front cover.

Ledingham, G. F. 1971. Alberta pictures. Blue Jay 29(3): 163.

Ledingham, G. F. 1971. [Editorial] Canadian Nature Federation. Blue Jay 29(4): inside front cover.

[Ledingham, G. F.] 1972. [Editorial] Snowmobiles in Saskatchewan. Blue Jay 30(1): inside front cover.

[Ledingham, G. F.] 1972. [Editorial] Universal concern about the environment. Blue Jay 30(2): inside front cover.

Ledingham, G. F. 1972. The Nature Conservancy of Canada. Blue Jay 30(2): 134-135.

[Ledingham, G. F.] 1972. [Editorial] Saskatchewan Department of the Environment. Blue Jay 30(3): inside front cover.

[Ledingham, G. F.] 1972. [Editorial] Blue Jay policy. Blue Jay 30(4): inside front cover.

Ledingham, G. F. 1973. In memoriam: Robert David Symons, 1898-1973. Blue Jay 31(3): 131-134.

Ledingham, G. F., and B. M. Pepper. 1973. Chromosome numbers of some South American species of Astragalus. Kurtziana 7: 27-37.

Ledingham, G. F., and S. D. Larmour. 1974. Some observations on the Pasque-flower. Blue Jay 32(1): 23-24.

Ledingham, G. F. 1977. Land use policy for Saskatchewan. Blue Jay 35(1): 5-11.

Ledingham, G. F. 1982. in M. Belcher, 'Vigilance needed in the Grasslands'. Blue Jay 40(2): 67-68.

Harms, V. L., and G. F. Ledingham. 1985. Mountain Lady'sslipper in Saskatchewan. Blue Jay 43(1): 3-6.

Ledingham, G. F. 1985. Grasslands National Park. Blue Jay 43(2): 98-101.

Raju, M. V. S., G. J. Jones, and G. F. Ledingham. 1985. Floret anthesis and pollination in wild oats (Avena fatua). Canadian Journal of Botany 63(12): 2187-2195.

Harms, V. L., J. H. Hudson, and G. F. Ledingham. 1986. Rorippa truncata, the Blunt-fruited Yellow Cress, new for Canada and $R$. tenerrima, the Slender Yellow Cress, in southern Saskatchewan and Alberta. Canadian FieldNaturalist 100(1): 45-51. 
Harms, V. L., and G. F. Ledingham. 1986. The narrowleaved Cat-tail, Typha angustifolia, and the hybrid Cat-tail T. $\times$ glauca newly reported from Saskatchewan. Canadian Field-Naturalist 100(1):107-110.

Ledingham, G. F. 1987. How will we celebrate the second wildlife centennial? Blue Jay 45(4): 188-191.

Ledingham, G. F. 1992. Others who remember Isabel M. Priestly: George F. Ledingham. Blue Jay 50(3): 154.

\section{Reviews}

Ledingham, G. F. 1959. Review of Moss, Flora of Alberta. Blue Jay 17(4): 172.

Ledingham, G. F. 1967. Review of Laycock, The Sign of the Flying Goose. Blue Jay 25(1): 48-49.

Ledingham, G. F. 1971. Review of Pimlott, Kerswill, and Bider, Scientific Activities in Fisheries and Wildlife Resources: a Background Study for the Science Council of Canada. Blue Jay 29(3): 148-150.
Ledingham, G. F. 1972. Review of Dirschl, Evaluation of Ecological Effects of Recent Low Water Levels in the Peace-Athabaska [sic] Delta. Blue Jay 30(2): 128-129.

Ledingham, G. F. 1972. Review of Hornby, Peace-Athabaska [sic] Delta: the Problems, Proposals and Action Taken. Blue Jay 30(2): 128-129.

Ledingham, G. F. 1978. Review of Hudson, Carex in Saskatchewan. Blue Jay 36(2): 124-125.

Ledingham, G. F. 1979. Review of Maher, Argus, Harms, and Hudson, The Rare Vascular Plants of Saskatchewan. Blue Jay 37(3): 188-189.

Ledingham, G. F. 1981. Review of Fisher, The Orchids of the Cypress Hills. Blue Jay 39(4): 246.

Ledingham, G. F. 1985. Review of Lynch, Married to the Wind. Blue Jay 43(1): 69-70.

Received 18 January 2013

Accepted 30 January 2013 